$1986,35,1$

\title{
THE FORMATION AND CHANGES OF ORGANIC MATTER IN THE PEATY (SAPROPELIC) STAGE CHARACTERIZED BY GROUP COMPOSITION DATA *
}

\author{
(Presented by $I$. Klesment)
}

The degree of transformation of oil shale organic matter has not been widely discussed. Oil shales, not yet as sapropelites but as a special group of solid fuels, have been classified as formations of brown coal and coal stages of transformation [1]. Sometimes, in the case of Souzak oil shale, for example, the peaty stage was also mentioned $\left[{ }^{2}\right]$. A. Dobryansky, however, differentiated sapropels and oil shales, regarding sapropels (interglacial and Holocene ones) as Quaternary oil shales [ $\left.{ }^{3}\right]$. A thought that oil shales are formations characterized by a low degree of catagenetic transformation has also been expressed [4]. On the basis of diagnostic value analysis of different features considered to be characteristic of sapropelic oil shale, it was pointed out that the oil shale organic matter must not be higher than the early mesocatagenetic stage of maturation, corresponding approximately to the long-flame stage of maturation in the case of humites [4]. But there is no certainty as yet of what known varieties of oil shale are in the brown coal and the coal stage of transformation. Neither has the lower limit, corresponding to the degree of transformation of the organic matter of sapropelic oil shale, been principally ascertained. In discussing the origin (sapropelic, humic and liptobiolitic) and the organic matter content $(10-50 \%)$ of oil shale, we considered the degree of oil shale transformation corresponding to the brown coal stage in the majority of cases $\left.{ }^{5}\right]$, like most of the investigators. But the depth-dependence investigation of the group composition of Holocene sapropel from Lake Lahepera that showed a decrease in the amount of easily hydrolyzable compounds with increasing quantities of alkali soluble necromic (the term induced us to unite sapropelic and humic acids $\left[{ }^{6}\right]$ ) and fulvic acids $\left[{ }^{7,8}\right]$, also common to peat and brown coal made us regard the degree of transformation of the known sapropelic oil shales as the late brown coal stage and the early coal stage in most cases [ $\left.{ }^{9}\right]$. The peaty (sapropelic) stage of transformation of organic matter in connection with oil shale genesis is the subject of the present report.

The problem of the early stages of organic matter transformation may be solved within the framework of V. Vernadsky's teaching of the biosphere and bio-inert systems, alone. Based on Vernadsky's doctrine of the biosphere $\left[{ }^{10}\right]$, one may arrive at a logical necessity to distinguish three kinds of matter, existing on the Earth: cosmic (abiogenic, косное $=$ inert), living and dead (biogenic, organogenic) $\left[{ }^{11,12}\right]$. Cosmic matter transforms into living matter, living matter into dead matter,

- Report at the 27th International Geological Congress, Moscow, August 1984. 
the latter within the limits of the biosphere (bio-inert system) is able to transform into living matter and back into the dead one:

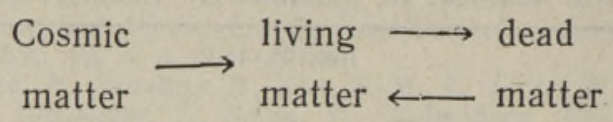

According to V. Vernadsky, the above system is a bio-inert system as is likewise the case with the organic formations of the Earth's crust in the peaty (or sapropelic) stage. The peaty (sapropelic) stage is a complex peculiar link in the chain of organic matter transformation on the Earth's crust. The formation of peat is assumed to proceed due to microbiological processes and chemical reactions and is therefore called «biochemical coalification» that turns into «geochemical coalification» proceeding without the action of microorganisms [ $\left.{ }^{13}\right]$. The boundary between the peaty and brown coal stage has not yet been finally determined, and neither has the exact lower boundary of the distribution of microorganisms. The organic formations of the Earth's crust in the peaty stage are somewhat different from the ancient ones: in most cases they contain, besides nonliving matter, also living matter in the forms of various organisms. Moreover, what is more important, the upper part of peat and sapropel formations borders on the atmosphere and hydrosphere, and within the limits of the phytospere it interacts with photosynthetic organisms accumulating solar energy and forming the primary production, without which all organic formations on the Earth's crust, i. e. dead matter, would be inconceivable. We do not deny the possibility of the existence on the Earth of organic formations from cosmic (abiogenic) matter, as, for example, those which are described by V. Ivanov and B. Klubov as abiogenic naphthoids [14] or other abiogenic formations.

The zone of primary production accumulation of bio-inert systems (the soil stage) principally differs from that in which only decomposition of the primary production proceeds accompanied by secondary synthesis of organic matter (the microbial stage). There may also be formations in the peaty stage without microorganisms. That is why we had to extend and specify the meaning of the peaty (sapropelic) stage. This suggests also a specification of the meaning of soil and soil distribution area in the weathering crust. So, soil has been defined as the upper layer of the weathering crust bearing higher plants, the underwater layer included. The thickness of the soil was determined by plants, i. e. by the depth of plant root penetration. For the primitive soils it is a relatively thin upper layer of the weathering crust, containing lower plants and photosynthesizing bacteria $\left[{ }^{15}, 16\right]$.

The organic matter of living organisms introduced into the upper layer of the lithosphere (into the weathering crust) is a type of sedimental rock formations $\left[{ }^{17}\right]$, the latter having not taken place on the Earth until the appearance of living matter or biosphere. That kind of consideration about soils and living and dead matter suggested-distinguishing in geology (in the broad sense of the term) biogeology, whose key subjects are soils (soil on dry land, underwater soil, soil on peat formations), that in turn allowed soils to return to geology. Our idea of biogeology is more comprehensive than that of A. Sidorenko and S. Sidorenko, who studied the organic matter of the deposited and metamorphised Precambrian rock formations and permitted an important conclusion about the tendency of biogeochemistry to develop towards biogeology $\left[{ }^{18}\right]$.

Again, in considering soil, peat and sapropel, it should be pointed out that these formations contain compounds which are typical of living 
organisms. This opinion may be confirmed by literature data on soil humus. So, microorganisms (bacteria, actinomycetes, fungi, algae) account for about $2-3 \%$ of the carbon of the entire soil humus, but carbohydrates, lipids, amino acids and other chemical compounds typical of the living matter are responsible for much more, i. e. $18-45 \%$ of the carbon of the soil $\left.{ }^{19}\right]$. Necromic and fulvic acids are specific to the nonliving organic matter of the geosphere, as well as humin and saprin. As a rule, they are absent in living matter. Judging by the group composition data of peat-producing plants $\left[{ }^{20}\right]$, they may be sometimes present in organisms or their parts in the final stage of their development. The matter of living organisms that is either in the active state or in anabiosis or has been killed during the experiment, to a greater or smaller extent dissolves and/or hydrolyzes in low-boiling solvents, water, diluted or concentrated acids or alkalis which are also useful in analyzing organic formations of the Earth's crust, especially those met with in the soil, in the microbial or peaty stage of organic

\section{Group composition analysis of organic formations according to $\left[{ }^{21}\right]$}

1. Extraction with methanol-benzene solution

Bitumoid A

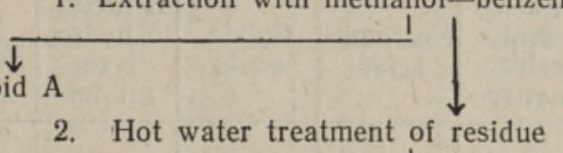

Hot water extract (sugars, starch, etc.)

3. Boiling water treatment of residue

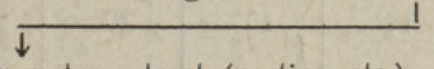

Boiling water extract (pectins, etc.)

4. Hydrolysis of residue with $2 \% \mathrm{HCl}$

Easily hydrolyzable compounds

(hemicellulose, etc.)

5. Extraction of residue with methanol-benzene solution

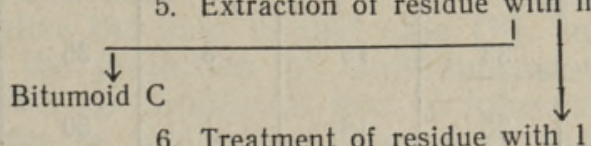

6. Treatment of residue with $1 \% \mathrm{NaOH}$ solution

Alkali-soluble matter

Acidification

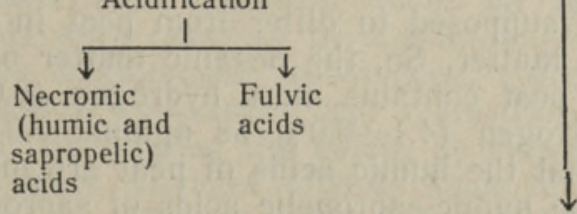

7. Hydrolysis of residue with $80 \% \quad \mathrm{H}_{2} \mathrm{SO}_{4}$

Substances that are difficult to hydrolyze (cellulose, etc.)

Residue (insoluble matter) 
matter transformation. The organic matter of dead organisms and metabolites of organisms in the geosphere finally becomes insoluble. There are several methods for group composition analysis of the organic matter at various stages of transformation. One of them is shown in Table 1 .

In each step of group composition analysis, certain chemical compounds are removed, but that process is not very selective. Nevertheless, group composition data are considered to be the most important chemical characteristics of the organic matter of peat, sapropel and brown coal, on the basis of which some important properties of these formations as a raw material for the production of, for example, wax; hydrolyzates, humic preparations, etc., have been elucidated.

Even sapropels from lakes located close together differ in group composition data $\left[{ }^{22,}{ }^{23}\right]$. As a rule, group composition data of samples from different depths of the same lake are also different $\left[{ }^{7}\right]$. On the other hand, the composition of some sapropels is similar to that of some peats (Table 2).

Table 2

Group composition data of algae, sapropel and peat, \%

\begin{tabular}{|c|c|c|c|c|c|c|c|}
\hline \multirow[b]{2}{*}{ Formation } & \multicolumn{6}{|c|}{ Components } & \multirow[b]{2}{*}{ Reference } \\
\hline & Bitumoid & $\begin{array}{l}\text { Easily } \\
\text { hydroly- } \\
\text { zable } \\
\text { matter }\end{array}$ & $\begin{array}{c}\text { Necromic } \\
\text { acids }\end{array}$ & $\begin{array}{l}\text { Fulvic } \\
\text { acids }\end{array}$ & $\left|\begin{array}{c}\text { Difficult } \\
\text { to hydro- } \\
\text { lyze } \\
\text { matter }\end{array}\right|$ & Residue & \\
\hline $\begin{array}{l}\text { Organic sapropel } \\
\text { (average) }\end{array}$ & 4 & 28 & 19 & 11 & 7 & 30 & {$\left[{ }^{20}\right]$} \\
\hline Lowland peat & 4 & 32 & 30 & 12 & 6 & 23 & {$\left[{ }^{25}\right]$} \\
\hline Blue-green algae & 6 & 55 & 13 & 17 & 10 & 1 & {$\left[{ }^{26}\right]$} \\
\hline Peat & 4 & 46 & 14 & 15 & 20 & 2 & {$\left[{ }^{20}\right]$} \\
\hline $\begin{array}{l}\text { Likhvian sapropel } \\
\text { from Körveküla, } \\
3.3-3.4 \mathrm{~m} \text { from } \\
\text { surface }\end{array}$ & 3 & 22 & 45 & 8 & 4 & 17 & Our data \\
\hline Reedpeat & 5 & 19 & 38 & 12 & 3 & 18 & {$\left[{ }^{25}\right]$} \\
\hline $\begin{array}{l}\text { Likhvian sapropel } \\
\text { from Körveküla, } \\
2.9-3.0 \mathrm{~m} \text { from } \\
\text { surface }\end{array}$ & 3 & 11 & 33 & 15 & 3 & 35 & Our data \\
\hline $\begin{array}{l}\text { Tropical coastal } \\
\text { peat }\end{array}$ & 3 & 12 & 35 & 18 & 1 & 30 & {$\left[{ }^{20}\right]$} \\
\hline
\end{tabular}

The problem is considerably clearer in case of such characteristics as the elemental composition of the organic matter of sapropel and peat or necromic acids. Sapropel is supposed to differ from peat in the elemental composition of organic matter. So, the organic matter of sapropel as compared with that of peat contains more hydrogen $(6.6-8.0 \%$ as against $5.0-6.0 \%)$ and nitrogen $(4.1-6.0 \%$ as against $1.0-3.5 \%)$ $\left[{ }^{22}\right]$. Moreover, it is believed that the humic acids of peat are more aromatic than the sapropelic or the humic-sapropelic acids of sapropel. The sapropelic acids are considered most aliphatic among the necromic ones.

What kind of additional cognitional information do the group composition data include besides information about the raw material properties became urgent to us after obtaining the group composition data of sapropels of South Estonian interglacial sites at Körveküla and Rõngu? 
The sapropel at Körveküla was deposited during the Likhvian interglacial about 300,000 years ago, being the oldest interglacial sapropel studied. The sapropel at Rõngu was deposited during the Mikulian interglacial. It was thought that interglacial sapropels must have been more transformed in comparison with the Holocene ones. But it turned out that the sapropel deposited during the interglacial did not contain more insoluble residue $(13.1-35.2 \%$, Table 3$)$ than most sapropels from Holocene lakes $\left(5-55 \%\left[{ }^{27}\right]\right)$. The amount of other group components varies also within the range common to Holocene sapropels [7, 22-24].

Table 3

Group composition data of interglacial sapropels at Rõngu and Kõrveküla (South Estonia), \%

\begin{tabular}{l|c|c|c|c|c|c}
\hline $\begin{array}{l}\text { Interval } \\
\text { from surface, } \\
\mathrm{m}\end{array}$ & $\begin{array}{c}\text { Bitumoid } \\
\mathrm{A}\end{array}$ & $\begin{array}{c}\text { Easily } \\
\text { hydro- } \\
\text { lyzable } \\
\text { matter }\end{array}$ & $\begin{array}{c}\text { Bitumoid } \\
\mathrm{C}\end{array}$ & $\begin{array}{c}\text { Sapro- } \\
\text { pelic } \\
\text { acids }\end{array}$ & $\begin{array}{c}\text { Fulvic } \\
\text { acids }\end{array}$ & $\begin{array}{c}\text { Difficult } \\
\text { to hydro- } \\
\text { lyze } \\
\text { matter }\end{array}$ \\
\hline
\end{tabular}

Rõngu

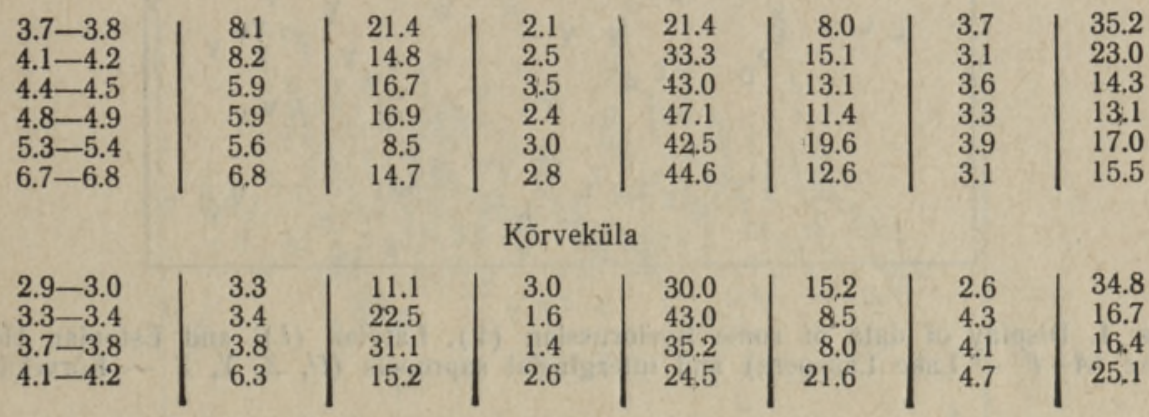

In our study 6 parameters are available for sapropels, peats and other organic formations and each sample can be thought to be situated in a 6-dimensional space. Pattern recognition techniques are often used to visualize the data in that case $\left[{ }^{28}\right]$. In our case, to check clustering, we use the projection of multidimensional data in a 2-dimensional space with no significant loss of information. So, in order to elucidate differences or similarities between oil shale, peat, brown coal, coal and interglacial and Holocene sapropels on the basis of group composition data, we used the visual cluster analysis by projecting data on the plane of two principal components. Part of group composition data was taken from literature, those on some Holocene and interglacial sapropels were obtained by the authors of the present paper. Bitumoid A, easily hydrolyzable substances, necromic and fulvic acids, difficult to hydrolyze substances and nonhydrolyzable residue (Table 1) were used to characterize the object by cluster analysis. The yields of bitumoid $\mathrm{C}$ were not used directly since they were not given in most publications. So, in case when these yields were determined, we had to reckon bitumoid $\mathrm{C}$ in necromic acids. That approach has also been confirmed by the data of T. Kukharenko $\left[{ }^{29}\right]$ who indicated that the unseparated bitumoids increase the humic (and also sapropelic) acid yield. In this way we used group composition data obtained by similar methods of analysis. 
The projection of data showed that sapropels have been grouped according to the location of lakes (Fig. 1). Estonian and Latvian sapropels differ from Byelorussian ones. This grouping of sapropels may be partly due to the differences in the details of the group composition analysis techniques used.

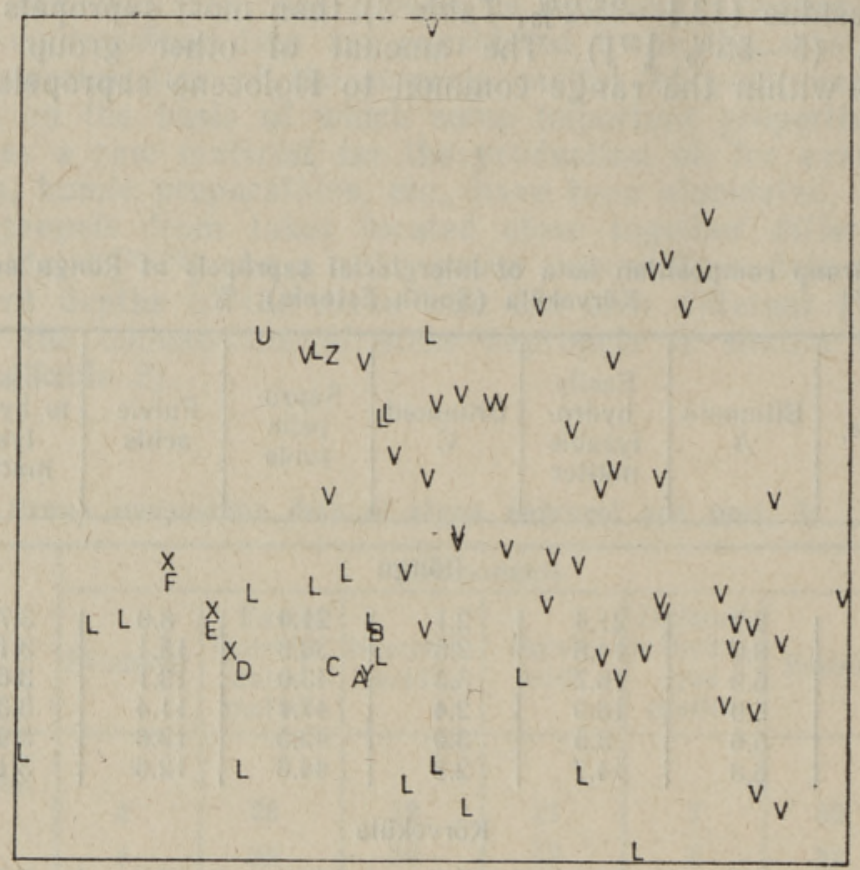

Fig. 1. Display of data of some Byelorussian (V), Latvian $(L)$, and Estonian Holocene $(A-F-$ Lake Lahepera) and interglacial sapropels $(U, X, Y, Z-$ Körveküla).

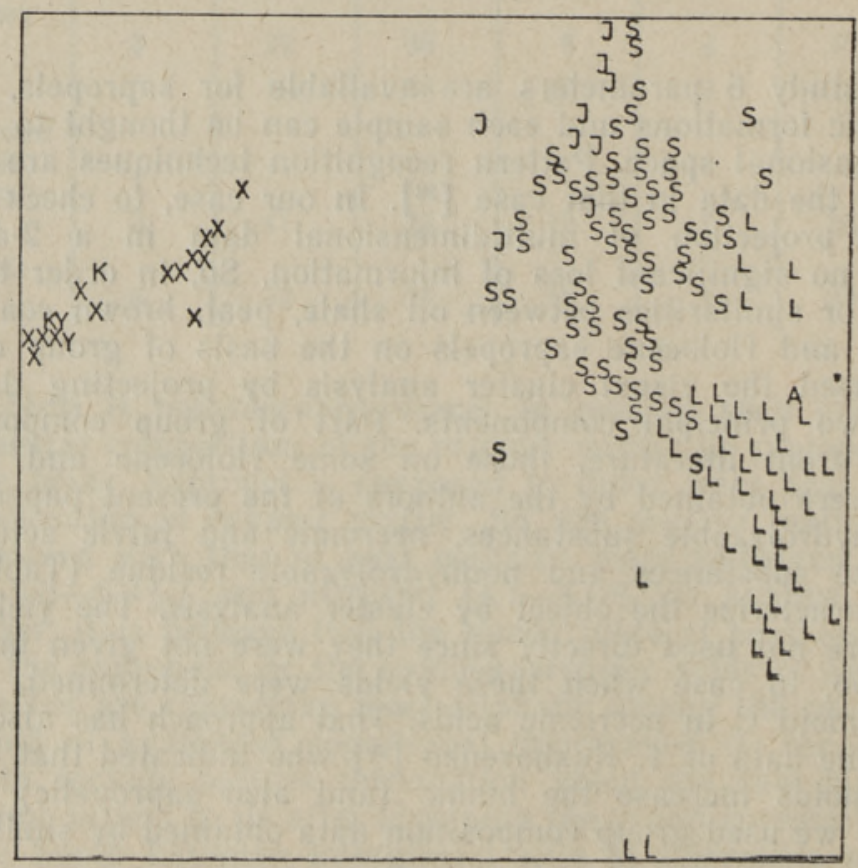

Fig. 2. Display of data of algae $(A)$, other plants $(L)$, Holocene sapropels $(S)$, interglacial sapropels $(J)$, oil shales $(X)$, weathered oil shales $(K)$, and bogheads $(Y)$. 
Fig. 2 visualizes the group composition data of oil shales, sapropels and plants. Plants and sapropels occupy the right-hand, and the oil shales the left-hand side of the plane. The interglacial sapropels are slightly different from the Holocene ones as they occupy the top right-hand area, including also some marks of Holocene sapropels, among them a 7-metre boring of Lake Lahepera. Plants form a separate cluster. Fig. 3 visualizes the group composition data of caustobioliths of sapropelic and humic origin and plants from which the former originate. In the display we can see that the marks corresponding to the humic organic matter cover almost the whole area between the plants and coals and oil shales. Sapropels, even the interglacial ones, lie separately, apart from oil shales, which phenomenon becomes clearly evident from Figs 2 and 3 . So sapropels are not similar to oil shales in group composition data.

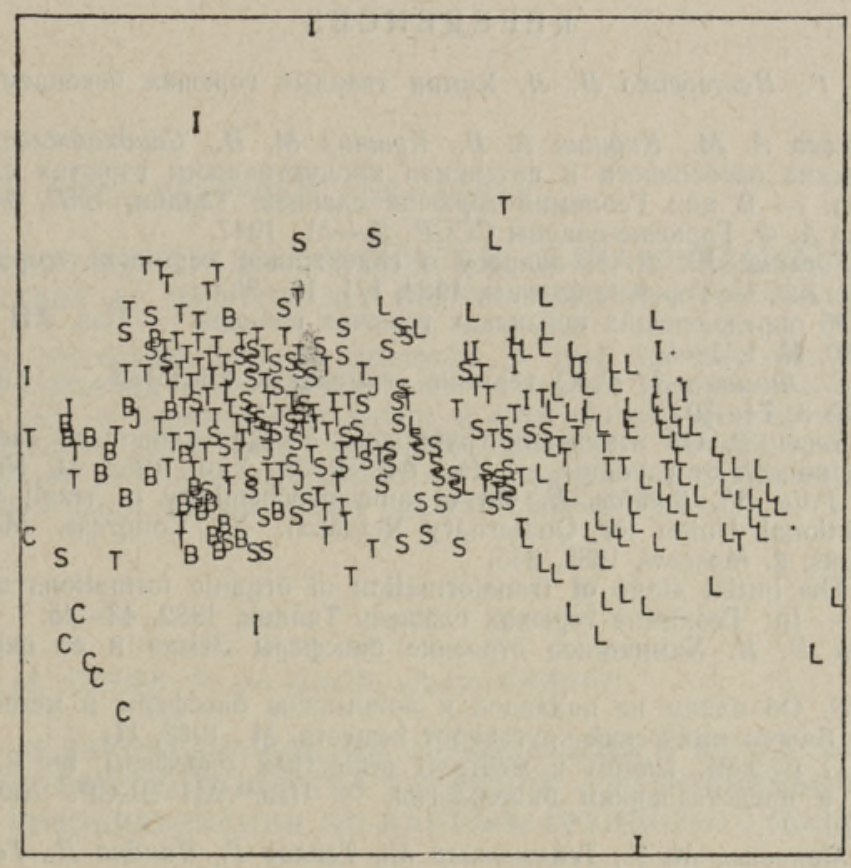

Fig. 3. Display of data of plants $(L)$, their parts $(I)$, Holocene sapropels $(S)$, and peats $(T)$, interglacial sapropels $(J)$, buried peats $(B)$, oil shales and coals $(C)$.

Although sapropels and peats lie at the initial stage of two different genetic lines of caustobioliths, in the display they occupy an area in common. So, sapropels generally do not differ from peats in group composition. The major part of the marks corresponding to peats are projected in the same area as various sapropels (organic, calcareous, etc.).

Group composition analysis data, visualized by cluster analysis; lead to a logical conclusion that sapropelic oil shale cannot be in the peaty (sapropelic) stage, as coals are not recognized in the peaty stage. Sapropelic oil shales should also be in the early brown coal stage, but in regard to group composition they are not yet known and require further study. According to group composition data, all the widely known sapropelic formations called oil shales can be classified as formations of late brown coal or early coal stage of transformation, 
since oil shale organic matter as well as that of sapropelic coals and coals of humic origin is mostly insoluble.

Thus, in nature, sapropelic and humic organic matter occurs in the same stages, i.e. in the soil, microbial, peaty, brown coal, coal, anthracite, etc. stages of transformation. Among them oil shales, like coals are the formations from the brown coal stage.

From the above it follows that it is possible to use group composition for clustering sapropelites and humites according to chemical age and find out common ways of transformation of their organic matter. It can be concluded that the main differences between these formations are not in the quantitative group composition data but in the qualitative chemical differences between some of their components; the necromic acids and nonhydrolyzable residue in the first place.

\section{REFERENCES}

1. Аронов С. Г., Нестеренко Л. Л. Химия твердых горючих ископаемых. Харьков, 1960.

2. Акрамходжаев А. М., Кириин А. В., Куинир М. И., Саидходжсаев Ш. Г. Геохимические особенности и потенциал продуктивности горючих сланцев Узбекистана. - В кн.: Геохимия горючих сланцев. Таллин, 1982, 9-10.

3. Добрянский А. Ф. Горючие сланцы СССР. Л.-М., 1947.

4. Уров К., Горький Ю. Н. К вопросу о содержании терминов жгорючий сланец» и «кероген». - Горючие сланцы, 1984, I/1, 16-23.

5. Вески Р. Об определяющих признаках горючих сланцев. - Изв. АН ЭССР. Хим., 1981, 30, № 1, 1-4.

6. Вески Р. Э., Фомина А. С. О термине «гуминовые кислоты». - Хим. тв. топл., 1978 , № 3, 74-79.

7. Палу В., Вески Р. Об изменении группового состава сапропеля озера Лахепера в зависимости от глубины. - Изв. АН ЭССР. Хим., 1982, 31, № 2, 136-140.

8. Veski, R., Palu, V., Bondar, E. On organic geochemistry of small lakes. - In: International Union for Quaternary Research. XI Congress. Moscow, 1982. Abstracts, 2. Moscow, 1982, 345 .

9. Veski, R. The initial stage of transformation of organic formations of the earth's crust. - In: Геохимия горючих сланцев. Таллин, 1982, 43-45.

10. Вернадский В. И. Химическое строение бносферы Земли и ее окружения. М., 1965.

11. Вески Р. Э. Об одном из подходов к пониманию биосферы и мегабиосферы. В кн.: Биогеохимнческий круговорот веществ. М., 1982, 11.

12. Вески Р. О косном, живом и мертвом веществах бносферы, по В. И. Вернадскому и представлениям биогеологии. - Изв. АН ЭССР. Хим., 1983, 32, № $11,70-77$.

13. Штах Э., Маковски М. Т., Тейхмюллер М., Тейлор $Г$., Чандра Д., Тейхмюллер $Р$. Петрология углей. М., 1978.

14. Нванов В. В., Клубов Б. А. Нафтоиды и нафтиды Северо-Востока СССР. М., 1979.

15. Вески Р. Э. Почвоведение и науки о биокосных системах. - Почвоведение, 1982 , № $12,18-25$.

16. Вески Р. Об органических образованиях земной коры, с точки зрения почвоведения и органической геохимин. - Изв. АН ЭССР. Хим., 1983, 32, № 1, 64-69.

17. Вески Р. Э. Об условиях захоронения органического вещества в земной коре. В кн.: Бногеохимические аспекты формирования осадочных пород и руд. Л., $1983,11-12$.

18. Сидоренко A. B., Сидоренко С. A. Органическое вещество в докембрийских осадочно-метаморфических породах и некоторые геологические проблемы. Сов. геол., 197 ; 1 , № $5,3-20$.

19. Паников Н. С., Садовникова Л. К., Фридланд Е. В. Неспецифнческие соединения почвенного гумуса. М., 1984.

20. Раковский В. Е., Пигулевская Л. В. Химия и генезис торфа. М., 1978.

21. Казаков E. И. Методика компонентного анализа органичесќoго вещества сапропелей. - В кн.: Методика изучения сапропелевых отложений, вып. 1. М., $1953,30-48$.

22. Позняк В. С., Раковский В. Е. О хнмическом составе органической массы сапропелей Белорусской ССР. - В кн,: Химия и генезис торфа и сапрөпелей. Минск, 1962, 299-308. 
23. Бракщ Н., Дубава Л., Браки И., Логина К. Сапропелевые отложения водоемов Латвнйской ССР. Рига, 1967.

24. Евдокимова Г. А., Пунтус Ф. А., Лопотко М. З., Прузан В. В., Каспарович Л. К., Макеева $Г$. П., Дубовец А. Г., Дубинин С. К. Характеристика группового и элементного состава органического вещества сапропелей БССР. - В кн.: Новые процессы и продукты переработки торфа. Минск, 1982, 48-53.

25. Раковский В. Е., Позняк В. С. Химическое исследование торфов БССР. - В кн.: Химия и генезис торфа и сапропелей. Минск, 1962, 30-43.

26. Раковский B. E. Химическая сущность процессов диагенеза торфа. - В кн.: Органнческое вещество современных и ископаемых осадков. М., 1971, $120-$ 142.

27. Лопотко М. З. Озера и сапропель. Минск, 1978.

28. Джурс П., Айзенауер T. Распознавание образов в химии. М., 1977.

29. Кухаренко T. А. Методы определения содержания гуминовых кислот в твердых горючих ископаемых. - Химия и технология топлива, 1956, № 5, 32-43.

Academy of Sciences of the Estonian SSR, Institute of Chemistry

Received

Institute of Geology

R. VESKI, M. KOEL, Vilja PALU, Leili SAARSE

\section{TURBA (SAPROPEELI) STAADIUMIS OLEVA ORGAANILISE AINE TEKKEST JA MUUTUSTEST GRUPIKOOSTISE ANDMETE POHJAL}

Sapropeelide, põlevkivide, turvaste, pruunsüte ja neid moodustavate taimede orgaanilise aine sarnasuse vôi erinevuse selgitamiseks kasutati grupikoostise andmeid ja klasteranalüüsi. Leiti, et sapropeelid ja turbad ei erine oluliselt grupikoostise poolest. Grupikoostise andmete põhjal saab senituntud põlevkivisid arvata moodustisteks, mis asuvad pruunsöe ja kivisöe algstaadiumides, kusjuures põlevkivide esinemine pruunsöe algstaadiumides nôuab veel täiendavat eksperimentaalset tōestust.

\section{Р. ВЕСКИ, М. КОЭЛЬ, Вилья ПАЛУ, Лейли СААРСЕ}

\section{О ЗАКОНОМЕРНОСТЯХ ОБРАЗОВАНИЯ И ИЗМЕНЕНИЯ ОРГАНИЧЕСКОГО ВЕЩЕСТВА ТОРФЯНОИ (САПРОПЕЛЕВОИ) СТАДИИ ПРЕОБРАЗОВАНИЯ ПО ДАННЫМ ГРУППОВОГО СОСТАВА}

Для выяснения сходства или различия органического вещества сапропелей, горючих сланцев, торфов, бурых углей и их исходного биоматериала - растений - привлечены данные группового состава этих образований и метод кластерного анализа. По данным группового анализа установлено, что сапропели мало отличаются от торфов. На этом основании предполагается, что формации, известные как горючие сланцы, находятся на конечных буроугольных и начальных каменноугольных стадиях преобразования. Отнесение горючих сланцев к начальным буроугольным стадиям требует дополнительных экспериментальных доказательств, 